\title{
Developing a Measurement of and Approaches to Brand Equity of Phuket, Thailand In the Perceptions of the European Market
}

\author{
Dr.Wasan Janprasit \\ Lecturer of Communication Arts Department \\ Faculty of Management Science, Phuket Rajabhat University \\ Asst. Prof. Dr.Oratai Krutwaysho \\ Lecturer of Tourism Management Department \\ Faculty of Business Administration, Rajamangala University of Technology Lanna
}

\begin{abstract}
Drawing on the number of tourists and revenue from tourism, Phuket is the most popular destination in Thailand. Additionally, European tourists is the most potential market in terms of the number of foreign tourists in Phuket (Ministry of Tourism and Sport of Thailand, 2018). This study therefore aimed to 1) develop a measurement model to measure the customerbased brand equity (CBBE) for Phuket as a destination in the perspectives of European tourists and 2) propose approaches to destination branding and marketing communication management with the purpose of creating added value for Phuket as a tourism destination brand. A mixed methodology was used by employing both qualitative and quantitative approaches. The results confirmed that, in addition to the four constructs proposed by previous studies (i.e., Gartner \& Ruzzier, 2011; Hsu, \& Assaf, 2012; Im, Kim, Elliot, \& Han, 2012; Konecnik, 2006; Konecnik \& Gartner, 2007; Pike, 2007, 2010), perceived value (both functional and emotional dimensions) and brand reliability are two components of customer-based brand equity for a tourism destination (CBBETD), particularly in a Thai context. Based on the perspectives of European tourists, the results also highlighted that brand loyalty is the most important component for building up CBBETD. Among the six components of CBBETD, the research found that brand awareness has the highest mean score. Accordingly, this study proposed practical approaches to Phuket destination branding and marketing communication management with the aim of creating higher CBBE for Phuket as a destination for the European market.
\end{abstract}

Key words: Customer-based brand equity for tourism destination; Destination brand; European tourists; Marketing communication; Tourism management 